\title{
New species of the endemic Neotropical caddisfly genus Contulma from the Andes of Ecuador (Trichoptera: Anomalopsychidae)
}

\author{
Ralph W Holzenthal ${ }^{\text {Corresp., }}{ }^{1}$, Blanca Ríos-Touma ${ }^{2}$, Ernesto Rázuri-Gonzales ${ }^{1}$ \\ 1 Department of Entomology, University of Minnesota, St. Paul, Minnesota, United States \\ 2 Facultad de Ingenierías y Ciencias Agropecuarias, Universidad de las Americas, Quito, Ecuador \\ Corresponding Author: Ralph W Holzenthal \\ Email address: holze001@umn.edu
}

The genus Contulma Flint (Trichoptera: Anomalopsychidae) is composed mostly of regionally endemic species occurring above $2000 \mathrm{~m}$, with a few more widespread species and some that are found at lower elevations. Adults of 3 new species of Contulma are described and illustrated from the Andes of Ecuador, Contulma lina, new species, Contulma quito, new species, and Contulma sangay, new species. These species are similar to previously described species from the region, including C. paluguillensis, $C$. nevada, and C. lancelolata. New provincial records are provided for C. bacula, C. cataracta, and C. echinata. Contulma duffi Oláh, 2016 is considered a junior, subjective synonym of C. penai, Holzenthal \& Flint, 1995. Also, we provide an identification key to males of the 30 Contulma species now known. 
1 New species of the endemic Neotropical caddisfly genus Contulma from the Andes of 2 Ecuador (Trichoptera: Anomalopsychidae)

3

4 Ralph W. Holzenthal ${ }^{1 *}$ Blanca Ríos-Touma ${ }^{2}$, Ernesto Rázuri-Gonzales ${ }^{1}$

$5{ }^{1}$ Department of Entomology, University of Minnesota, St. Paul, Minnesota, USA

$6{ }^{2}$ Universidad de las Américas, Facultad de Ingenierías y Ciencias Agropecuarias, Quito, 7 Ecuador

8

9

10

11

* Corresponding author=Ralph Holzenthal, holze001@umn.edu 
13 Abstract. The genus Contulma Flint (Trichoptera: Anomalopsychidae) is composed mostly of 14 regionally endemic species occurring above $2000 \mathrm{~m}$ in Central and South America, with a few 15 more widespread species and some that are found at lower elevations. Adults of 3 new species of 16 Contulma are described and illustrated from the Andes of Ecuador, Contulma lina, new species, 17 Contulma quito, new species, and Contulma sangay, new species. These species are similar to 18 previously described species from the region, including C. paluguillensis, C. nevada, and C. 19 lancelolata. New provincial records are provided for C. bacula, C. cataracta, and C. echinata. 20 Contulma duffi Oláh, 2016 is considered a junior, subjective synonym of C. penai, Holzenthal \& 21 Flint, 1995. Also, we provide an identification key to males of the 30 Contulma species now 22 known. 


\section{Introduction}

25

26 Neotropical Trichoptera currently includes more than 3,200 described species representing 155

27 genera and 25 families (Holzenthal \& Calor, 2017) occurring in Mexico, the Caribbean, Central, 28 and South America. Remarkably, 115 genera, or ca.75\% of the total, are endemic to the region, 29 making the fauna the second most diverse in the world for endemic genera after the Australasian

30 (de Moore \& Ivanov, 2008). Moreover, several Neotropical genera are highly endemic regionally at the species level such as Amphoropsyche Holzenthal (Holzenthal, 1985, Holzenthal \& RázuriGonzales, 2011), Atananolica Mosely (Holzenthal, 1988, Henriques-Oliveira \& Santos, 2014), and Contulma Flint (Holzenthal \& Robertson, 2006), the latter the main subject of this paper. Nevertheless, the Neotropical caddisfly fauna is incompletely known, mainly because there are regions in the Neotropics where the aquatic ecosystems are far from being well studied (e.g., Ríos-Touma, Holzenthal, Huisman, Thomson, \& Rázuri-Gonzales, 2017). There is also a lack of regional researchers studying the order, especially in the Andean countries of Venezuela, Colombia, Ecuador, Peru, and Bolivia, which undoubtedly harbor 100s of species. For example, co-authors Ríos-Touma is the first Ecuadorian to describe new species of caddisflies and RázuriGonzales only the second Peruvian to do so.

A comprehensive revision of the endemic Neotropical genus Contulma was completed by Holzenthal \& Flint (1995) and included 21 species, 18 described as new. Since then, 7 new species have been described, including 1 we synonymize here (Table 1). Species in the genus are known from Costa Rica, the Andes of Colombia to Chile, and in the mountains of southeastern Brazil (Holzenthal \& Calor, 2017). This genus seems to display a high degree of local endemism among its species (Holzenthal \& Robertson, 2006), and they are rarely collected using standard light trap techniques. Hand netting during the day, especially at high elevations, or the use of Malaise traps is generally more effective (Holzenthal \& Ríos-Touma, 2012). The infrequency of collection does not mean the species are rare in nature, but most have been described from only 1-5 individuals. Perhaps this is a reflection of minimal collecting effort or low temperatures at high elevations that reduce adult flying activity. The habitats of these species are small waterfalls, seeps, and small streams in lush forested mountainous areas as well as high elevation páramo streams above the tree line in the Andes (Holzenthal \& Flint, 1995).

4 Of the 30 species now known in the genus, including 3 new species described here, 19 
55 occur in the tropical Andean countries (Ecuador, Colombia, Peru, Bolivia) and all occur above

$562000 \mathrm{~m}$, except for 2 of these species also found in lower elevations (Holzenthal \& Flint, 1995,

57 Holzenthal \& Robertson, 2006). Eight species occur in Ecuador, 5 endemic and 3 are also

58 present in Colombia. The 3 new species described here are from localities were no caddisfly

59 collecting occurred previously.

60

61 Materials and Methods

62

63 We used the methods described by Blahnik \& Holzenthal (2004) to prepare adult specimens for 64 taxonomic study. Genitalia were cleared in $85 \%$ lactic acid heated to $125^{\circ} \mathrm{C}$ for $20 \mathrm{~min}$ (Blahnik, 65 Holzenthal, \& Prather, 2007). An Olympus BX41 compound microscope outfitted with a 66 67 68 69 drawing tube was used to observe specimens. Genital structures were drawn with pencil on paper and final illustrations were rendered in Adobe Illustrator. Morphological terminology follows that of Holzenthal \& Flint (1995). Descriptions of species and generation of the identification key were accomplished using the software packages DELTA and INTKEY (Dallwitz, 1980, Dallwitz, Paine, \& Zurcher, 1999).

1

Types of the new species are deposited in the collections of the Museo Ecuatoriano de Ciencias Naturales, Quito, Ecuador (MECN) and the University of Minnesota Insect Collection,

3
St. Paul, Minnesota, USA (UMSP). All specimens examined in this study were affixed with a barcode label containing a unique 9 digit numeric code starting with the prefix UMSP. These codes are provided here for holotypes only. All associated specimen data are stored in the UMSP database. This study was performed under the Environmental Ministry of Ecuador study permits 36-2010-IC-FLO/FAU-DPA-MA and 005-15-IC-FAU-FLO-DNB/MA.

8

The electronic version of this article in Portable Document Format (PDF) will represent a published work according to the International Commission on Zoological Nomenclature (ICZN), and hence the new names contained in the electronic version are effectively published under that

81 Code from the electronic edition alone. This published work and the nomenclatural acts it 83 ZooBank LSIDs (Life Science Identifiers) can be resolved and the associated information viewed 84 through any standard web browser by appending the LSID to the prefix http://zoobank.org/. 85 The LSID for this publication is: urn:Isid:zoobank.org:pub:54BC56DC-5CC1-4DA0-82E4- 
86

87

88

89

90

91

92

93

94

95

96

97

98

99

100

101

102

103

104

105

106

107

108

109

110

111

112

113

114

115

116

AF69599C2F5D. The online version of this work is archived and available from the following digital repositories: PeerJ, PubMed Central and CLOCKSS.

\section{Results}

Species descriptions

\section{Contulma lina, new species, Holzenthal, Ríos-Touma, Rázuri-Gonzales}

LSID urn:1sid:zoobank.org:act:310DDC54-0008-4535-A385-BD71BB630F21

Figures 1A-E, 2

Diagnosis: Contulma lina, n. sp., as well as C. quito, n. sp., and the recently described $C$. paluguillensis Holzenthal \& Ríos-Touma, 2012, in addition to C. echinata, C. nevada, and C. papallacta, all described by Holzenthal \& Flint (1995), and all from either Ecuador or Colombia, share several features. All have some degree of development of a dorsolateral process on segment IX in the male genitalia and a development of setae or a setose process on the mesal face of the same segment below the dorsolateral process. These 3 species formed a clade within the cranifer-group of Holzenthal \& Flint (1995) to which C. lina, n. sp., C. quito, n. sp., and C. paluguillensis also belong. In some species, one or the other of these characters may be more or less developed, but the combination of characters shared by these species indicate that they may have a common origin. The phallic structures seem to be unique to each species and attest to their distinctiveness. All are known from only a handful of specimens, most from only the type and a few paratypes, and the species each occur from only one or a few high altitude localities spread across a vast expanse of the northern Andes. We predict that additional collecting will discover yet more new species in this radiation of Andean Trichoptera biodiversity. Contulma lina is distinguished from the above mentioned species, all illustrated by Holzenthal \& Flint (1995) and Holzenthal \& Ríos-Touma (2012), by the following combination of characters: mesal surface of segment IX bearing a sinuous band of setae from below dorsolateral process and continuing to near sternum IX; mesal process of sternum IX with prominent posteromesal, heavily sclerotized, spatulate projection, without excavation; and phallus without spine-like 
117 setae, but instead with the apex bearing a lightly sclerotized scale-like structure, shallowly 118 excavate at apex.

119 Description: Male: Forewing length $5.5 \mathrm{~mm}(\mathrm{n}=1)$. Forewing color gray brown, immaculate, 120 vestiture rubbed (specimen was netted during the day in light rain and mist). Male genitalia:

121 Segment IX very short dorsally, narrow, deeply excavate mesally; in lateral view, IX quadrate, 122 extended anterolaterally; posteriorly with short, broad, dorsolateral, spatulate process; posterior 123 margin of IX produced medially to form broad, prominent, quadrate, heavily setose, paired

124 lateral lobes; lobes widely separated ventrally; mesal face of segment IX bearing sinuous band of 125 setae from below spatulate process continuing to near sternum IX; sternum IX with prominent 126 posteromesal, heavily sclerotized, spatulate projection. Inferior appendages short, subtriangular, 127 apices broadly rounded and bearing apical setae; inferior appendages apparently fused to base of 128 IXth sternal projection, together forming highly complex structure as in Figs. 1A, C. Processes of 129 subphallic membranes present, membranous, mound-like, setose. Segment X entirely 130 membranous, apex entire, extending beyond apices of dorsolateral processes. Phallus complex; 131 phallobase tubular, elongate, slender, sclerotized; phallicata very lightly sclerotized, dorsally 132 with paired, very lightly sclerotized, semi-membranous lobes; apicoventral phallic membranes 133 with paired, broad, lightly sclerotized, dorsolateral plates, membranes inflated anteroventrally, 134 apically with lightly sclerotized scale-like structure, shallowly excavate at apex; phallotremal 135 sclerite present, tubular, curved.

136 Female: Forewing length $6.5 \mathrm{~mm}(\mathrm{n}=1)$. Color and vestiture as in male. Vaginal apparatus in 137 ventral view elongate, hourglass shaped, narrowest in middle; base widely emarginate, 138 subtriangular; apex trident shaped with wide, paired, sclerotized, slightly sinuate midlateral 139 processes, their apices truncate; single medial process elongate, narrow, slerotized, about same 140 length as midlateral processes; medial membranes highly convoluted, as approximated in Fig. 2; 141 apical membranes highly convoluted, with heavily sclerotized, rounded, beaklike apical sclerite.

142 Holotype male: ECUADOR: Napo: Reserva Ecológica Cayambe-Coca, waterfall, rd. to 143 Oyacachi, $0.32621^{\circ} \mathrm{S}, 78.15049^{\circ} \mathrm{W}$, el. 3690 m, 16.x.2011, Holzenthal, Ríos-Touma, Pita 144 (UMSP000098532) (UMSP). Paratype: same data as holotype, 1 female (MECN).

145 Etymology: This species in named for Lina Pita, lifelong friend of Blanca Ríos-Touma and 
146 one of the collectors of this species.

147

148 Contulma quito, new species, Holzenthal, Ríos-Touma, Rázuri-Gonzales

149 LSID urn:1sid:zoobank.org:act:97969526-CF58-48A8-8548-8817326D04A0

150

151 Figures $3 \mathrm{~A}-\mathrm{F}$

152

153 Diagnosis: This new species is very similar to $C$. nevada of the group of species mentioned

154 above (C. echinata, C. lina, C. nevada, C. paluguillensis, and C. papallacta). Contulma quito, $\mathrm{n}$.

155 sp., and C. nevada have similar short dorsolateral processes on segment IX, a small setal patch or

156 setal bearing process below the dorsolateral process, emarginate sternal projection of sternum IX,

157 and short spines in the phallus. The major differences between C. quito and C. nevada are the

158 broader excavation of the IXth sternal projection and the many more spine-like setae in the

159 phallus of C. quito.

160 Description: Male: Forewing length $5.5 \mathrm{~mm}(\mathrm{n}=3)$. Forewing color brown, with small patch

161 of cream colored hairs at apex of subcosta and arculus, vestiture intact. Male genitalia: Segment

162 IX very short dorsally, narrow, deeply excavate mesally; in lateral view, IX quadrate, slightly

163 extended anterolaterally; posteriorly with very short, narrow, dorsolateral, spatulate process;

164 posterior margin of IX produced medially to form broad, prominent, broadly rounded, heavily

165 setose, paired lateral lobes; lobes widely separated ventrally; mesal face of segment IX with

166 short, sclerotized, setose process below spatulate process. [Variation: in male paratype

167 UMSP000148995, the spatulate processes and the short setose processes below them are each

168 fused on both sides of the specimen to form a thin, crecentic shelf (Fig. 3F). In male paratype

169 UMSP000148996, the spatulate processes and the setose processes below them are variously

170 slightly longer or shorter on either the right or left sides than they are in the holotype]. Sternum

171 IX with prominent posteromesal, heavily sclerotized, strongly emarginate projection. Inferior

172 appendages short, crescentric, apices rounded and bearing apical setae; inferior appendages

173 apparently fused to base of IXth sternal projection, together forming highly complex structure as

174 in Figs. 3A, C. Processes of subphallic membranes present, membranous, mound-like, setose.

175 Segment X entirely membranous, apex divided, with lightly sclerotized lateral flanges. Phallus

176 complex; phallobase tubular, elongate, slender, sclerotized; phallicata very lightly sclerotized, 
177 dorsally with paired, very lightly sclerotized, semi-membranous lobes; apicoventral phallic

178 membranes with paired, broad, lightly sclerotized, dorsolateral plates forming broadly rounded

179 trough, apicoventrally with paired patches of numerous (ca. 50) very short spine-like setae;

180 phallotremal sclerite very lightly sclerotized, difficult to discern.

181 Female: Unknown.

182 Holotype male: ECUADOR: Pichincha: Distrito Metropolitano de Quito, Quebrada 183 Guapalito, $0.40113^{\circ} \mathrm{S}, 78.38378^{\circ} \mathrm{W}$, el. $2807 \mathrm{~m}, 26 . v i i .2015$, Rázuri, Ríos-Touma, Amigo

184 (UMSP000148997) (UMSP). Paratypes: ECUADOR: Pichincha: Distrito Metropolitano de 185 Quito, Quebrada Convalescencia, $0.40060^{\circ} \mathrm{S}, 78.38256^{\circ} \mathrm{W}$, el. $2813 \mathrm{~m}, 26$. vii.2015, Morabowen, 186 Hernández, 2 males (UMSP, MECN).

187

188

Etymology: Named for Quito, the capital of Ecuador, where the species was collected and where the surrounding Andes seem to harbor a multitude of species in the genus.

189

Contulma sangay, new species, Holzenthal, Ríos-Touma, Rázuri-Gonzales

192

193

Figures 4A-D, 5

194

195 LSID urn:1sid:zoobank.org:act:38C17810-F31C-45A5-BFAC-3D3C5E68AD47

Diagnosis: This new species is similar to C. lanceolata, Holzenthal \& Flint, 1995, also from Ecuador. Both share a similar shape of segment IX, which is strongly extended anterolaterally and with the posterior portion excavated medially in both species. In addition, both have an elongate dorsolateral setose lanceolate process on segment IX, but in C. sangay the process is divided apically into a pair of narrow, terete lobes. Most distinctively, the new species lacks the

Description: Male: Forewing length $4.5 \mathrm{~mm}(\mathrm{n}=1)$. Forewing color brown, immaculate, 203 vestiture intact. Male genitalia: Segment IX short dorsally, narrow; in lateral view, IX trapezoidal, strongly extended anterolaterally; posteriorly with elongate, dorsolateral, lanceolate process, apically divided into pair of terete, narrow, closely appressed lobes; process bearing 
206 minute setae dorsally along length; posterior margin of IX excavated medially, produced

207 ventrally, to form prominent, semiquadrate, setose, paired lateral lobes; lobes close together

208 ventrally, forming acute separation; mesal face of segment IX without setae or processes;

209 sternum IX short, subquadrate projection, its suface rugose and with very small, mesal

210 sclerotized spur. Inferior appendages very short, crescentric, apices subacute, directed ventrally,

211 and bearing apical setae; inferior appendages apparently fused to base of IXth sternal projection,

212 together forming highly complex structure as in Figs. 4A, C. Processes of subphallic membranes

213 absent (or not apparent). Segment X entirely membranous, apex cleft, extending to apices of

214 dorsolateral processes. Phallus complex; phallobase tubular, elongate, slender, sclerotized;

215 phallicata very lightly sclerotized, dorsally with prominent membranous lobe; apicoventral

216 phallic membranes with paired, broad, lightly sclerotized, ventrolateral plates, fused ventrally

217 and forming apparent pore, apex with pair of small papillate lobes; phallotremal sclerite present,

218 small, subquadrate.

219 Female: Forewing length $4.5 \mathrm{~mm}(\mathrm{n}=1)$. Color as in male, but vestiture rubbed. Vaginal 220 apparatus in ventral view short, oval, widest in middle; base rounded, urn-shaped; apex trident 221 shaped with narrow, paired, lightly sclerotized, indistinct midlateral processes, their apices acute; 222 single medial process elongate, narrow, sclerotized, longer than midlateral processes; medial 223 membranes highly convoluted, as approximated in Fig. 5; apical membranes highly convoluted, 224 with lightly sclerotized, broad, thin, shelf-like apical sclerite.

225 Holotype male: ECUADOR: Morona-Santiago: Río Salado, Highway E46 (via Riobamba226 Macas), $2.24253^{\circ} \mathrm{S}, 78.27791^{\circ} \mathrm{W}$, el. 1646 m, 26.i.2015, Holzenthal, Huisman, Ríos-Touma, 227 Amigo (UMSP000147014) (UMSP). Paratype: same data as holotype, 1 female (MECN).

228 Etymology: Named for the type locality, Sangay National Park, where the species was 229 collected from the Río Salado.

\section{New Provincial Records}

232

233 Contulma bacula Holzenthal \& Flint, 1995:11 [Type locality: Ecuador, Napo, 1 mi E of Pa234 pallacta; type depository: NMNH; holotype male]. -Medellín, Ramírez, \& Rincón, 
2004:201 [distribution; biology]. - Holzenthal \& Calor, 2017:21 [catalog].

236 Distribution. Colombia, Ecuador.

237 New provincial record: ECUADOR: Morona-Santiago: Río Tinguichaca; Highway E46 (via

238 Riobamba-Macas), 02.21474º $\mathrm{S}, 078.44218^{\circ} \mathrm{W}$, el. $2772 \mathrm{~m}, 25 . \mathrm{i} .2015$, Holzenthal, Huisman,

239 Ríos-Touma, Amigo, 1 male, 2 females (UMSP).

240

Contulma cataracta Holzenthal \& Flint, 1995:12 [Type locality: Ecuador, Napo, Río Maspa Chico, 2 km W Cuyuja; type depository: NMNH; holotype male]. — Holzenthal \& Calor, 2017:22 [catalog].

244 Distribution. Ecuador.

245 New provincial record: ECUADOR: Morona-Santiago: Sangay National Park, waterfall 2,

$2462.18111^{\circ} \mathrm{S}, 78.5062^{\circ} \mathrm{W}$, el. $3516 \mathrm{~m}, 12 . x i .2015$, Ríos-Touma, Thomson, Amigo, 3 males, 1

247 female (UMSP).

248

Contulma echinata Holzenthal \& Flint, 1995:15 [Type locality: Colombia, Caldas, 5 km W

250

251

Termales de Ruíz; type depository: NMNH; holotype male; female]. —Muñoz-Quesada,

252 2000:274 [checklist]. —Holzenthal \& Calor, 2017:22 [catalog].

Distribution. Colombia, Ecuador.

254

New provincial record: ECUADOR: Napo: Reserva Ecológica Cayambe-Coca, waterfall, rd.

to Oyacachi, $0.32621^{\circ} \mathrm{S}, 78.15049^{\circ} \mathrm{W}$, el. $3690 \mathrm{~m}, 16 . x .2011$, Holzenthal, Ríos-Touma, Pita, 1

256

257 male (UMSP); same, except 26.ii.2012, Ríos-Touma and Pita, 1 male (UMSP).

Contulma penai Holzenthal \& Flint, 1995:18 [Type locality: Ecuador, Zamora-Chinchipe, 30

260

261

262 km E Loja; type depository: NMNH; holotype male; female; larva]. - Muñoz-Quesada, 2000:274 [checklist]. —Holzenthal \& Calor, 2017:23 [catalog].

\section{New synonymy}

_Contulma duffi Oláh, 2016:169 [Type locality: Colombia, Antioquia, Dusky Starfrontlet Bird Reserve, Cordillera Occidental, Urrao, $6^{\circ} 25^{\prime} \mathrm{N}, 75^{\circ} 05^{\prime} \mathrm{W}, 9.11 .2014$, caught by hand, leg. A.G. Duff; type depository: private collection of J. Oláh; holotype male] NEW SYNONYM Distribution. Colombia, Ecuador. 
267 Contulma duffi, described from Antioquia, Colombia, fits clearly within the variation we have

268 seen in the species C. penai, which also occurs in Antioquia, Colombia, and Ecuador, where it is

269 rather common compared to other species in the genus. There are no features illustrated or

270 diagnosed in the original description that distinguish the species from C. penai. Most of the

271 characters discussed by Oláh (2016) are those common to the genus as a whole. The

272 membranous structure of tergum $\mathrm{X}$ is identical in both species. The dorsolateral processes of

273 segment IX are illustrated as slightly curved in $C$. duffi compared to those illustrated for $C$.

274 penai, but this slight difference is variable, and the inferior appendages are identical in the 2

275 species. In Oláh's diagnosis, the species is said to be most similar to C. bacula, but it shares little

276 in common with that species. The inferior appendages, the posteromesal process of sternum IX,

277 and the phallus are completely different between the 2 species.

278

\section{Key to Males of Contulma Species ${ }^{1}$}

280 1. Posterior margin of segment IX with dorsolateral processes (HF 24, 44, 58, 79, 90,

281 107) (these processes may be short, but present, as in C. quito, Fig. 3A, B)

282 Posterior margin of segment IX without dorsolateral processes, although there may be small setose projections or patches of setae (HF 40, 48, 49, 86, 95, 112)

284 2(1). Dorsolateral processes of segment IX very long, slender, strongly down curved, their

285 apices rugose (HF 107, HR 2A, 4A)

Dorsolateral processes of segment IX shorter and/or differently shaped, their apices not rugose.

Phallus with pair of large, highly membranous convoluted dorsolateral lobes (in some specimens these lobes may not evert during the clearing process) (HR 2D-F, 4D-E) ....

${ }^{1}$ Citations of previously published illustrations referenced in the key are abbreviated as follows: $\mathrm{HF}=\mathrm{Holzenthal} \&$ Flint, 1995, HR= Holzenthal \& Robertson, 2006, JN=Jardim \& Nessimian, 2011, HRT=Holzenthal \& Ríos-Touma, 2012. 
291

292

293 4(3).

294

295

296

297

298

299

300

301

302 6(2).

303

304

305

306

$307 \quad 7(6)$.

308

309

310 8(7).

311

312

313

314

315

Phallus without highly membranous convoluted lobes or with much smaller, less well-developed lobes (HF 110, JN 5) 5

Segment IX extended anterodorsally (HR 4A); setose lobe of posterior margin of segment IX situated close to middle of segment (HR 4A)

Contulma tripui

Segment IX only slightly extended anterodorsally, if at all (HR 2A); setose lobe of posterior margin of segment IX situated close to ventral margin of segment (HR 2A)..

Contulma fluminensis

5(3). Posterior margin of segment IX extended into a long, narrow, acute, setose lobe (JN $1)$.

Contulma sana

Posterior margin of segment IX extended into a much shorter, subtriangular, setose lobe (HF 107)

Contulma tijuca

Phallus with pair of large, highly membranous convoluted dorsolateral lobes (in some specimens these lobes may not evert during the clearing process) (HF 28, 33, 56, 93).

Phallus without highly membranous convoluted lobes or with much smaller, less well-developed lobes (HF 81) 10

Segment IX with pair of elongate, heavily setose, ventrolateral lobes (HF 24, 26)

Contulma adamsae

Segment IX without such lobes 8

Dorsolateral processes of segment IX, in lateral view, long, linear, directed ventrad along entire length (sinuous and crossing apically in dorsal view) (HF 52-53); segment IX very short dorsolaterally (HF 52); segment X membranous, almost obliterated (HF 53)

Contulma cranifer

Dorsolateral processes of segment IX, in lateral view, much shorter, linear to lorate, directed posteriad, apex only slightly to strongly directed ventrad (straight and not 
316

317

$3189(8)$

319

320

321

322

323

324

325

326

327

328

329

330

331

332

333

334

335

336

337

338

339

crossing apically in dorsal view); segment IX long dorsolaterally; segment X membranous, but well developed (HF 30, 31, 90)

9(8). Dorsolateral processes of segement IX, narrow, terete, apex slightly directed ventrad (HF 30-31)

Contulma bacula

Dorsolateral processes of segment IX lorate (strap-shaped with apex flexed), apex strongly directed ventrad (HF 90)

Contulma spinosa

10(6). Segment IX with mesolateral patch of long or short spine-like setae or with mesolateral setose protuberances (HF 57, 75, 79; HRT 1B; Figs. 1A, B, 3B) 11

Segment IX without mesolateral setae or setose protuberances

11(10). Apex of phallus with pair of large, tooth-like structures and/or with smaller apicoventral spines (HF 60, 81; Fig. 3D).

Apex of phallus without such spines, although small setae or papillae may be present .

12(11). Apex of phallus with pair of large, tooth-like structures and smaller apicoventral spines (HF 60)

Contulma echinata

Apex of phallus with pair of large, tooth-like structures only (HF 81)

Contulma papallacta

Apex of phallus with smaller apicoventral spines only (HF 77; Figs. 3D, E) ........... 13

13(12). Projection of sternum IX subtriangular in ventral view, with broad, angulate mesal excavation (Fig. 3C)

Contulma quito, new species

Projection of sternum IX quadrate in ventral view, with narrow mesal excavation (HF 76)

Contulma nevada

14(11). Mesolateral setae of segment IX forming sinuous band from below dorsolateral process continuing to near sternum IX (Figs. 1A, B); projection of sternum IX 
344 15(10). Segment IX extended anterodorsally (HF 44, 61, 70, 82; HR 1A; Fig. 4A); inferior

Segment IX only slightly extended anterodorsally, if at all (HF 66); inferior

16(15). Apex of phallus with pair of large, tooth-like structures (HF 64, 65); tergum IX with

Apex of phallus without such spines, although small setae or papillae may be present;

17(16). Dorsolateral processes of segment IX clothed with short, fine setae (HF 44, 71, 82;

18(17). Dorsolateral processes of segment IX curved mesally, widely separated, subtriangular (HF 44-46)

Contulma colombiensis

358
Dorsolateral processes of segment IX straight, parallel, directed downward, close together, lanceolate

19(18). Segment IX posteriorly with only single long dorsolateral or lateral setose process or none at all 20 Segment IX posteriorly with both long dorsolateral setose process and long, slender, sharply pointed, ventrolateral process (HF 70-72) Contulma lanceolata 
364 20(19). Apex of dorsolateral processes of segment IX entire (HF 82, 83)...... Contulma penai

365

366

367 21(1)

368

369

370

371

372

373

374

375

376

377

378

379

380

381

382

383

384

385

386

387
Apex of dorsolateral processes of segment IX divided into pair of terete, narrow, closely appressed lobes (Figs. 4A, B)

Contulma sangay, new species

21(1). Segment $X$ with lightly sclerotized lateral regions that apparently articulate basally with sclerotized projections of dorsolateral corners of segment IX (HF 48-49, 103104)

Segment $\mathrm{X}$ without lightly sclerotized lateral regions that apparently articulate basally with sclerotized projections of dorsolateral corners of segment IX 23

22(21). Segment IX with mesolateral patch of short spine-like setae (HF 48-49); projection of sternum IX truncate (HF 50); parameres long, slender (HF 51)

Contulma costaricensis

Segment IX without mesolateral setae (HF 104); projection of sternum IX acute apically (HF105); parameres short (HF 106)

Contulma tica

23(21). Phallus with pair of large, highly membranous convoluted dorsolateral lobes (in some specimens these lobes may not evert during the clearing process) (HF 42-43, 89, 114$115)$ 24

Phallus without highly membranous convoluted lobes or with much smaller, less well-developed lobes 26

24(23). Segment IX with mesolateral patch of long (HF 39-40) or short (HF 86) spine-like setae.

Segment IX without mesolateral setae or setose protuberances (HF 111-112)

Contulma valverdei

25(24). Dorsolateral membranous lobes of phallus each ending in sclerotized, scale-like process (HF 42-43); projection of sternum IX long, rounded (entire) apically (HF 41). 
391 26(23). Segment IX with mesolateral patch of long or shorter spine-like setae (HF 95, 100) or

Apex of phallus with large, apicoventral spines (HF 97-98); parameres absent

28(27). Segment IX with patch of long, stout, spine-like mesolateral setae (HF 100); smaller setae may be present (HF 36); phallicata with parameres only, lateral flanges absent (HF 38)

Contulma caldensis

${ }^{2}$ Contulma meloi is a member of the group of species including C. fluminensis, C. sana, $C$. tijuca, and $C$. tripui from southeastern Brazil. However, it lacks the very long, slender, strongly downcurved, apically rugose dorsolateral processes of segment IX. The species is known only from the male holotype and a male paratype. In the holotype, there are no dorsolateral processes (HR 3A), but in the paratype, a rudimentary process occurs (HR 3G). However, it shares all other diagnostic features of this group, including the posterior, setose extension of segment IX, the broad, shelf-like structure of sternum IX, including the flat, tooth-like, apical setae, and the complex, membranous lobes of the phallus. It appears artificially in couplet 26 , separated from related species because it lacks the strongly downcurved, apically rugose dorsolateral processes indicated in couplet 2 . The collection of additional specimens may prove that the absence of the dorsolateral process is an aberration; if so, the specimens would lead to $C$. fluminensis in the key presented above. 
406 Contulma species appear to be highly regionally endemic (Holzenthal \& Flint, 1995, Holzenthal

407 \& Robertson, 2006). We observed this pattern in our collections in Ecuador. Patterns of high

408 endemicity in macroinvertebrate benthic larvae are well known in high altitude glacial streams;

409 these habitats are highly threatened by climate change (Jacobsen, Milner, Brown, \& Dangles,

410 2012). On the other hand, we added records to the Ecuadorian fauna of species that were

411 previously known only from Colombia, demonstrating that some species may have spread across

412 the Andes. Despite this distribution pattern, aquatic insect species, especially mayflies, have

413 shown genetic isolation in the various ranges of the Ecuadorian Andes, even with relatively short

414 distances between populations and with recent volcanic eruption history (Finn, Encalada, \&

415 Hampel, 2016). No similar study has yet been performed with any Andean caddisfly species, but

416 we expect a similar pattern of isolation among populations. This isolation could increase by the

417 intense land use changes and water pollution occurring throughout the inter-Andean valleys

418 (Ríos-Touma, Acosta, \& Prat, 2014) potentially preventing dispersal among mountain

419 populations and also local extinctions.

420

421 Acknowledgements

422

423 We thank Dr. Desi Robertson, Dr. Brian Armitage, Dr. Tatiana I. Arefina-Armitage, and an

424 anonymous reviewer for their constructive reviews of the manuscript. 
425

426

427

428

429

430

431

432

433

434

435

436

437

438

439

440

441

442

443

444

445

446

447

448

449

450

451

452

453

454

455

\section{References}

Blahnik RJ, Holzenthal RW. 2004. Collection and curation of Trichoptera, with an emphasis on pinned material. Nectopsyche, Neotropical Trichoptera Newsletter 1:8-20.

Blahnik RJ, Holzenthal RW, Prather AL. 2007. The lactic acid method for clearing Trichoptera genitalia. In: Bueno-Soria J, Barba-Álvarez R, and Armitage BJ, eds. Proceedings of the 12th International Symposium on Trichoptera. Columbus, Ohio: The Caddis Press, 9-14.

Dallwitz MJ. 1980. A general system for coding taxonomic descriptions. Taxon 29:41-46.

Dallwitz MJ, Paine TA, Zurcher EJ. 1999. User's guide to the DELTA editor. Available from: http://delta-intkey.com/.

de Moor FC, Ivanov VD. 2008. Global diversity of caddisflies (Trichoptera: Insecta) in freshwater. Hydrobiologia 595:393-407.

Finn DS, Encalada AC, Hampel H. 2016. Genetic isolation among mountains but not between stream types in a tropical high-altitude mayfly. Freshwater Biology 61:702-714. $10.1111 /$ fwb. 12740

Henriques-Oliveira AL, Santos APM. 2014. Two new species of Atanatolica Mosely 1936 (Trichoptera: Leptoceridae) from Peru and Northeastern Brazil. Zootaxa 3869:537-547.

Holzenthal RW. 1985. Studies in Neotropical Leptoceridae (Trichoptera) II: Amphoropsyche, a new genus and species of Leptocerinae from northern South America. International Journal of Entomology 27:255-269.

Holzenthal RW. 1988. Studies in Neotropical Leptoceridae (Trichoptera), VIII: the genera Atanatolica Mosely and Grumichella Müller (Triplectidinae: Grumichellini). Transactions of the American Entomological Society 114:71-128.

Holzenthal RW, Calor AR. 2017. Catalog of the Neotropical Trichoptera (Caddisflies). ZooKeys 654:1-566. 10.3897/zookeys.654.9516

Holzenthal RW, Flint OS, Jr. 1995. Studies of Neotropical caddisflies, LI: systematics of the Neotropical caddisfly genus Contulma (Trichoptera: Anomalopsychidae). Smithsonian Contributions to Zoology 575:1-59.

Holzenthal RW, Rázuri-Gonzales LE. 2011. A new species of Amphoropsyche (Trichoptera, Leptoceridae) from Ecuador, with a key to the species in the genus. ZooKeys 211:59-65. Holzenthal RW, Ríos-Touma B. 2012. Contulma paluguillensis (Trichoptera: 
456

457

458

459

460

461

462

463

464

465

466

467

468

469

470

471

472

473

474

475

476

477

478

Anomalopsychidae), a new caddisfly from the high Andes of Ecuador, and its natural history. Freshwater Science 31:442-450. 10.1899/11-067.1

Holzenthal RW, Robertson DR. 2006. Four new species of Contulma from South America (Trichoptera: Anomalopsychidae). Zootaxa 1355:49-59.

Jacobsen D, Milner AM, Brown LE, Dangles O. 2012. Biodiversity under threat in glacier-fed river systems. Nature Climate Change 2:361-364.

Jardim GA, Nessimian JL. 2011. A new species of Contulma Flint (Trichoptera, Anomalopsychidae) from southeastern Brazil. Revista Brasileira de Entomologia 55:226228.

Medellín CF, Ramírez OM, Rincón ME. 2004. Trichoptera del Santuario de Iguaque (Boyacá, Colombia) y su relación con la calidad del agua. Revista Colombiana de Entomología 30:197-203.

Muñoz-Quesada F. 2000. Especies del orden Trichoptera (Insecta) en Colombia [Colombian species of the order Trichoptera (Insecta)]. Biota Colombiana 1:267-288.

Oláh J. 2016. New species and records of Trichoptera collected by Mr. A. G. Duff. More phenomics and less genomics! Opuscula Zoologica (Budapest) 47:155-171. http://doi.org/10.5281/zenodo.167120

Ríos-Touma B, Acosta R, Prat N. 2014. The Andean Biotic Index (ABI): revised tolerance to pollution values for macroinvertebrate families and index performance evaluation. Revista de Biologia Tropical 62 (suppl 2):249-273.

Ríos-Touma B, Holzenthal RW, Huisman J, Thomson R, Rázuri-Gonzales E. 2017. Diversity and distribution of the Caddisflies (Insecta: Trichoptera) of Ecuador. PeerJ 5:e2851. $10.7717 /$ peerj. 2851 


\section{Figure 1 (on next page)}

Contulma lina, new species, male genitalia.

Figure 1. Male genitalia of Contulma lina, new species. (A) segments IX and $X$, lateral (base of phallus indicated in crosshatch). (B) segments IX and X, dorsal. (C) segment IX, ventral. (D) phallus, lateral. (E) phallus apex, dorsal. Abbreviations: $I X=$ abdominal segment $\mathrm{IX} ; \mathrm{X}=$ abdominal segment $\mathrm{X}$. 


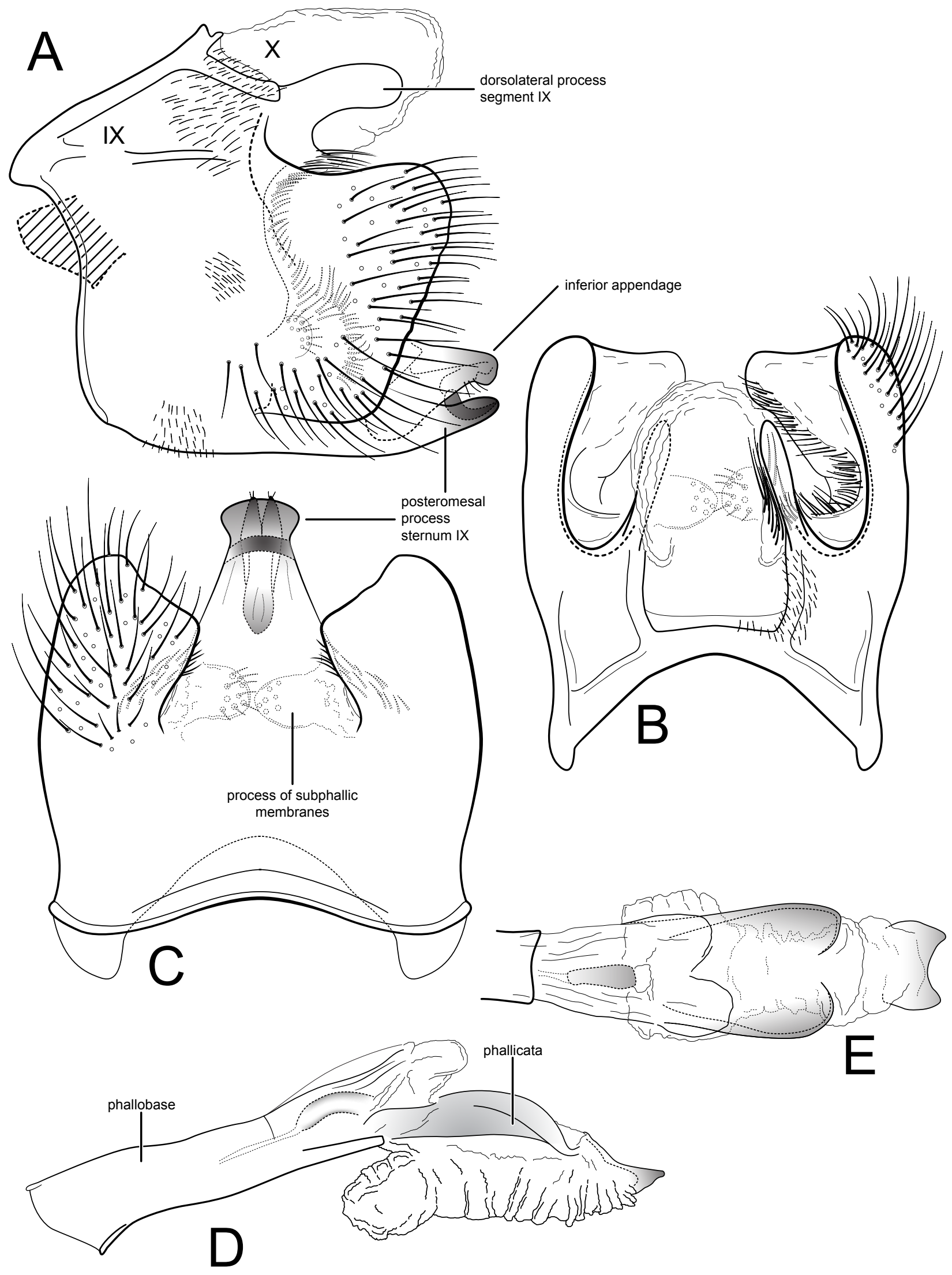


Figure 2 (on next page)

Contulma lina, new species, female vaginal apparatus.

Figures 2. Female vaginal apparatus of Contulma lina, new species, ventral. 
PeerJ

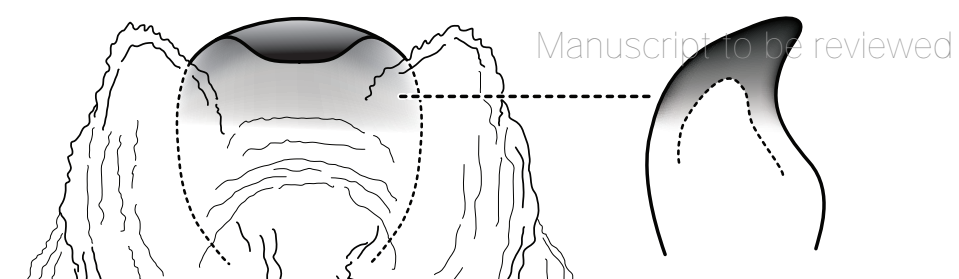


Figure 3 (on next page)

Contulma sangay, figure 3

Figure 3. Male genitalia of Contulma quito, new species. (A) segments IX and $X$, lateral (base of phallus indicated in crosshatch). (B) segments XI and X, dorsal. (C) segment IX, ventral. (D) phallus, lateral. (E) phallus apex, dorsal. (F) segments IX and X, dorsal, variation in paratype specimen UMSP000148995. 

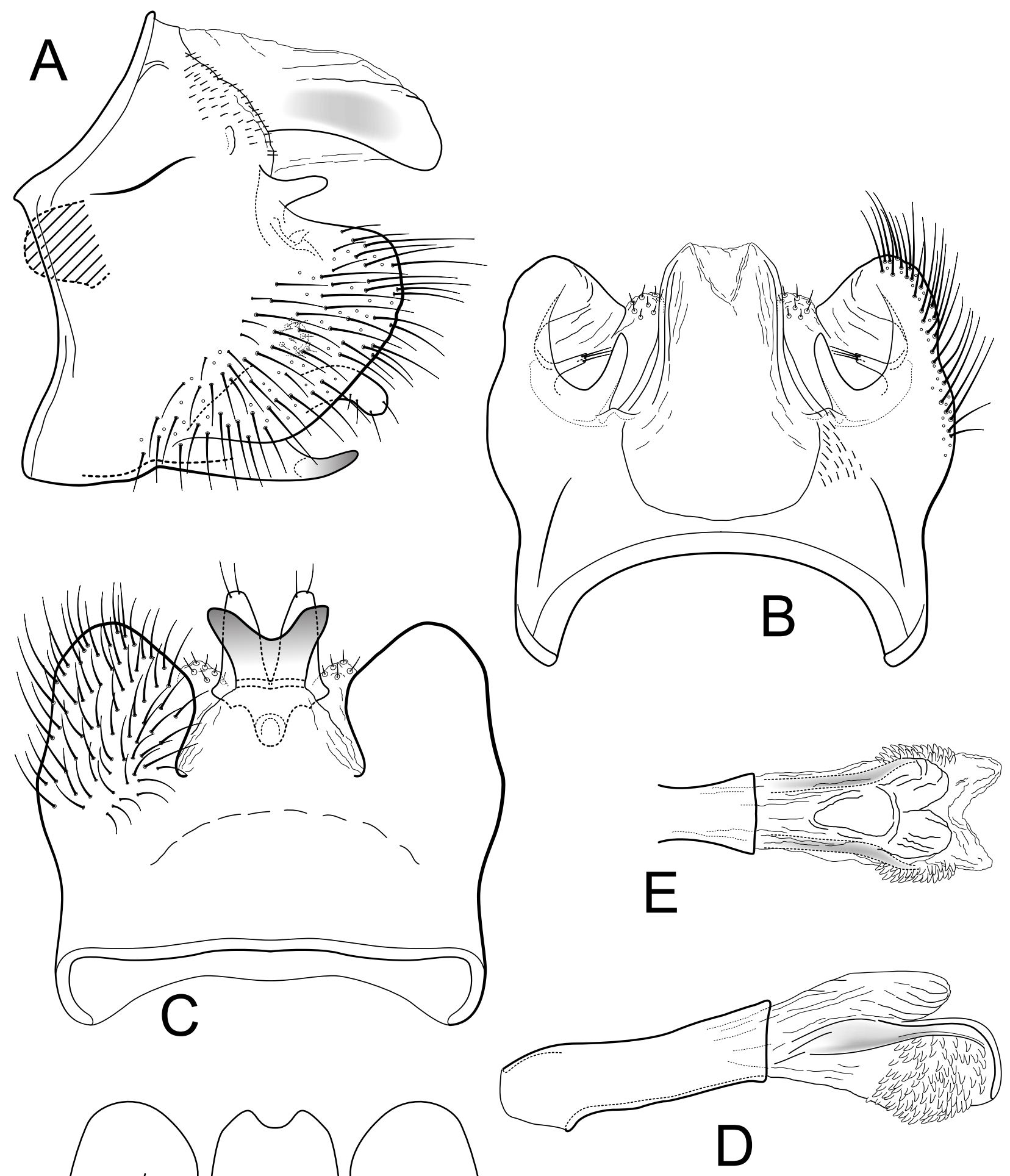


\section{Figure 4 (on next page)}

Contulma sangay, new species, male genitalia.

Figure 3. Male genitalia of Contulma sangay, new species. (A) segments IX and X, lateral (base of phallus indicated in crosshatch); inset: apex of inferior appendage, caudal. (B) segments XI and X, dorsal. (C) segment IX, ventral. (D) phallus, lateral; insets: details of phallic structures. 


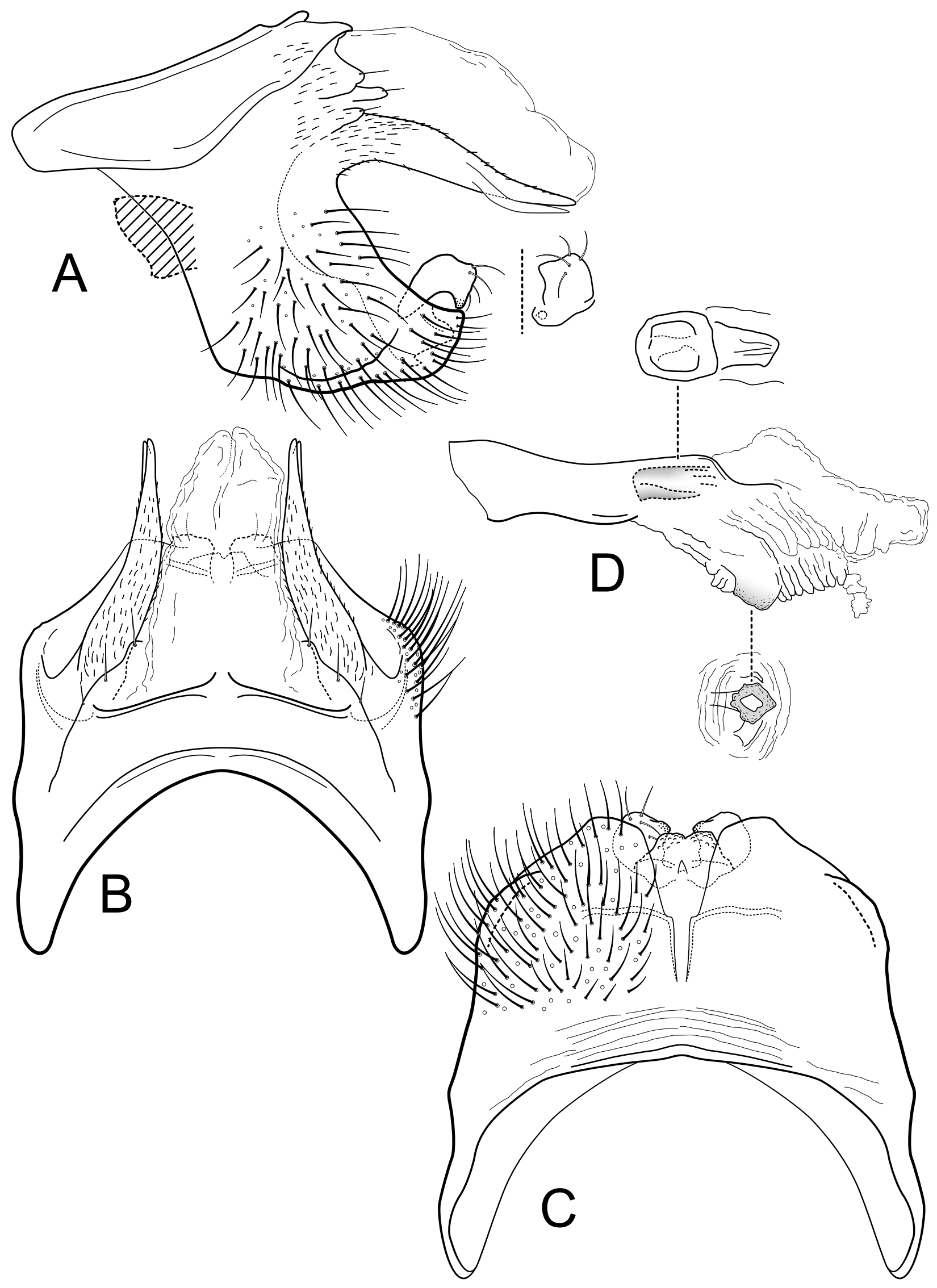


Figure 5 (on next page)

Contulma sangay, new species, female vaginal apparatus.

Figures 5. Female vaginal apparatus of Contulma sangay, new species, ventral. 
PeerJ

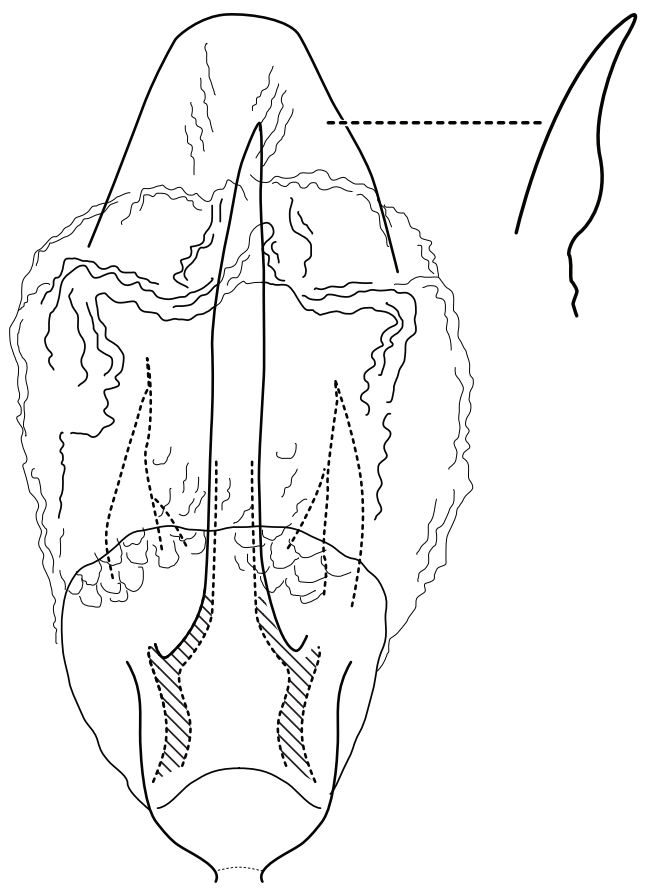




\section{Table $\mathbf{1}$ (on next page)}

Described species in the genus Contulma with geographic distribution and known life stages. 
Table 1. Described species in the genus Contulma with geographic distribution and known life stages.

\begin{tabular}{|c|c|c|c|}
\hline Species & Author & Distribution & Known stages \\
\hline Contulma adamsae & Holzenthal \& Flint, 1995 & Peru & male, female \\
\hline Contulma bacula & Holzenthal \& Flint, 1995 & Colombia, Ecuador & male \\
\hline Contulma boliviensis & Holzenthal \& Roberson, 2006 & Bolivia & male \\
\hline Contulma caldensis & Holzenthal \& Flint, 1995 & Colombia & male \\
\hline Contulma cataracta & Holzenthal \& Flint, 1995 & Ecuador & male \\
\hline Contulma colombiensis & Holzenthal \& Flint, 1995 & Colombia & male, female \\
\hline Contulma costaricensis & Holzenthal \& Flint, 1995 & Costa Rica & male \\
\hline Contulma cranifer & Flint, 1969 & Chile & male, female \\
\hline Contulma echinata & Holzenthal \& Flint, 1995 & Colombia & male, female \\
\hline Contulma ecuadorensis & Holzenthal \& Flint, 1995 & Ecuador & male, female \\
\hline Contulma fluminensis & Holzenthal \& Roberson, 2006 & Brazil & male \\
\hline Contulma inornata & Holzenthal \& Flint, 1995 & Colombia & male \\
\hline Contulma lanceolata & Holzenthal \& Flint, 1995 & Ecuador & male \\
\hline Contulma lina, n. sp. & Holzenthal, Ríos-Touma, \& Rázuri-Gonzales, 2017 & Ecuador & \\
\hline Contulma meloi & Holzenthal \& Roberson, 2006 & Brazil & male \\
\hline Contulma nevada & Holzenthal \& Flint, 1995 & Colombia & male, female, larva \\
\hline Contulma paluguillensis & Holzenthal \& Ríos-Touma, 2012 & Ecuador & male, female, larva,pupa \\
\hline Contulma papallacta & Holzenthal \& Flint, 1995 & Ecuador & male \\
\hline Contulma penai & Holzenthal \& Flint, 1995 & Colombia, Ecuador & male, female, larva \\
\hline Contulma duffi Oláh, 2016, n. syn. & & & male \\
\hline Contulma quito, n. sp. & Holzenthal, Ríos-Touma, \& Rázuri-Gonzales, 2017 & Ecuador & \\
\hline Contulma sana & Jardim \& Nessimian, 2011 & Brazil & male \\
\hline Contulma sancta & Holzenthal \& Flint, 1995 & Costa Rica & male \\
\hline Contulma sangay, n. sp. & Holzenthal, Ríos-Touma, \& Rázuri-Gonzales, 2017 & Ecuador & \\
\hline Contulma spinosa & Holzenthal \& Flint, 1995 & Colombia, Ecuador & male, female, larva \\
\hline Contulma talamanca & Holzenthal \& Flint, 1995 & Costa Rica & male, female \\
\hline Contulma tapanti & Holzenthal \& Flint, 1995 & Costa Rica & male, female \\
\hline Contulma tica & Holzenthal \& Flint, 1995 & Costa Rica & male \\
\hline Contulma tijuca & Holzenthal \& Flint, 1995 & Brazil & male, female, probable larva \\
\hline Contulma tripui & Holzenthal \& Roberson, 2006 & Brazil & male \\
\hline Contulma valverdei & Holzenthal \& Flint, 1995 & Costa Rica & male, female, larva \\
\hline
\end{tabular}


